\title{
Variation in styles of rifting in the Gulf of California
}

Daniel Lizarralde ${ }^{1}$, Gary J. Axen ${ }^{2}$, Hillary E. Brown ${ }^{3}$, John M. Fletcher ${ }^{4}$, Antonio González-Fernández ${ }^{4}$, Alistair J. Harding ${ }^{5}$, W. Steven Holbrook ${ }^{3}$, Graham M. Kent ${ }^{5}$, Pedro Paramo ${ }^{3,7}$, Fiona Sutherland ${ }^{5,7}$, and Paul J. Umhoefer ${ }^{6}$

${ }^{1}$ Dept. of Geology and Geophysics, Woods Hole Oceanographic Institution

${ }^{2}$ Dept. of Earth \& Environmental Sciences, New Mexico Inst. of Mining and Technology

${ }^{3}$ Dept. of Geology and Geophysics, University of Wyoming

${ }^{4}$ Dept. of Geology, Centro de Invest. Científica y de Educación Superior de Ensenada

${ }^{5}$ Inst. of Geophysics and Planetary Physics, Scripps Institution of Oceanography

${ }^{6}$ Dept. of Geology, Northern Arizona Univ.

${ }^{7}$ BP Exploration Operating Company, London

The rifting of continental lithosphere is a fundamental solid-earth process that leads to the formation of rifted continental margins and ocean basins. Understanding of this process comes from observations of the geometry of rifted margins and the magmatism resulting from rifting, which inform us about the strength of the lithosphere, the state of the underlying mantle, and the transition from rifting to seafloor spreading. Here we describe results from the PESCADOR seismic experiment in the southern Gulf of California and present the first crustal-scale images across conjugate margins of multiple segments within a single rift that has reached the stage of oceanic spreading. A surprisingly large variation in rifting style and magmatism is observed between these segments, from wide rifting with minor syn-rift magmatism to narrow rifting in magmatically robust segments. These differences encompass much of the variation observed across nearly all other non-end-member continental margins. The characteristics of magmatic endmember margins are typically explained in terms of mantle temperature. Our explanations for the variation in the Gulf of California, in contrast, invoke mantle depletion to 
account for wide, magma-poor rifting and mantle fertility and possibly the influence of sediments to account for robust rift and post-rift magmatism in the Gulf of California. These factors may vary laterally over small distances in regions that have transitioned from convergence to extension, as is the case for the Gulf of California and many other rifts.

The most basic structural feature of a rift is its width. A range of rift widths is observed globally, with wide rifts defined as those with a total conjugate-margin width greater than $200 \mathrm{~km}^{(1)}$. Narrow rifts form in numerical models as necking instabilities ${ }^{2}$ provided extension rates outpace thermal diffusion ${ }^{3}$. Wide rifts require a mechanism to inhibit localization, and it is believed that flow within a weak lower crust, driven by buoyancy forces in high heat flow settings, plays this role in many wide rifts ${ }^{1,4}$. Parameterizations of mantle melting predict melt production as a function of lithospheric thinning ${ }^{5}$. Rifted margins with magmatic additions substantially greater or less than predicted for "normal” mantle potential temperature $\left(\sim 1350^{\circ} \mathrm{C}\right)$ can be referred to as magma-rich or magma-poor margins. End members range from volcanic margins, with 2-3 times predicted magmatism and voluminous subaerial eruptions, to non-volcanic margins, which exhibit almost no rift or post-rift magmatism. Volcanic margins are commonly explained as due to increased mantle potential temperature, and non-volcanic margins as due to conductive cooling at slow rates of extension. It is generally believed that mantle temperature also places the primary control on rift magmatism observed across non-end-member margins, such as those of the southern Gulf of California.

Many of the factors believed to control structural evolution and magmatism during rifting - extension rate, mantle potential temperature, and heat flow - tend to be regional in nature. Our results reveal structural and magmatic variations over small distances 
along the Gulf of California rift, suggesting that other factors also exert a first-order influence on rift evolution.

The Gulf of California is an oblique rift system with short spreading segments connected by long transform faults (Fig. 1) ${ }^{6}$. Rifting in the gulf began at $12-15 \mathrm{Ma}$ when subduction ended west of the Baja California peninsula. As the East Pacific Rise (EPR) approached the paleo-trench, the subducting Farallón plate broke into a number of microplates, and, as subduction stalled, those microplates and the Baja California peninsula coupled to the Pacific plate, resulting in the onset of rifting and eventually the modern plate boundary within the Gulf of California in the vicinity of the former $\operatorname{arc}^{7-10}$. The peninsula now moves nearly completely with the Pacific plate, with $\sim 48 \mathrm{~mm} / \mathrm{yr}$ of spreading across the Gulf of California representing 92\% of Pacific-North America relative motion ${ }^{11,12}$. No shear zones cut across the peninsula south of the Agua Blanca fault (Fig. 1, inset), and the Pacific/North American Euler pole is sufficiently distant that the rift segments of the southern gulf have all experienced the same net extension rate since rifting began.

Previously, little was known about the variation in rifted-margin crustal structure along the gulf, with constraints limited to geologic observations, seafloor bathymetry, gravity transects, sparse seismic refraction measurements ${ }^{13}$, and the CORTES-P96 ${ }^{14}$ crustal-scale seismic transect in the northern gulf (Fig. 1). The seafloor expression of rift structure is masked by sediments in much of the gulf, and the considerable variation in sediment thickness, from thick sediments in the north to little sediment input in the south, gives the impression that rift structure varies from narrow in the south to wide in the north. This impression is enhanced by the obscuring effect of sediment on the development of seafloor spreading magnetic lineations ${ }^{6}$, such that diagnostic magnetic lineations are only observed across the southernmost segments of the gulf. Our results 
indicate that a simple north-to-south variation does not exist in the southern gulf, south of Tiburon Island (Fig. 1). Instead, distinct styles of rifting and rift magmatism occur within the southern gulf, and this variation appears to be related to pre-rift magmatic history.

We acquired wide-angle and multi-channel seismic data across the northern Guaymas, Alarcón, and San José del Cabo to Puerto Vallarta (Cabo-PV) segments of the southern Gulf of California as part of the PESCADOR experiment. Each of these transects was instrumented with ocean-bottom seismometers spaced 10-15 km apart and similarly spaced seismometers on land recording the offshore shots to $\sim 100 \mathrm{~km}$ inland. Excellent quality data from this dense source and receiver coverage enable imaging of detailed crustal structure across these rift segments ${ }^{15-17}$ (Fig. 2 and Supp. Inf.). Each transect reveals a rifting style that is distinct in terms of structure and magmatism.

The Guaymas basin is a narrow rift segment that has been robustly magmatic since breakup. We estimate the location of the continent/ocean transition here based on the well constrained rapid shallowing of the Moho and coincident lateral increase in seismic velocity to $\sim 6.8 \mathrm{~km} / \mathrm{s}$, a value typical of gabbroic composition rock. We interpret the crust seaward of the continent/ocean transitions to be new igneous crust formed at an oceanic spreading centre that accommodated the majority of extension in this segment since lithospheric rupture. The spreading centre has been robustly magmatic, forming new intrusive igneous crust 6 to $8 \mathrm{~km}$ thick, with an additional unknown volume of igneous material intruded into the overlying sediments. The $\sim 280 \mathrm{~km}$ width of new igneous crust and spreading rates of $\sim 48 \mathrm{~mm} / \mathrm{yr}$ imply that lithospheric rupture occurred at 6 Ma. Lithospheric rupture followed at least $70 \mathrm{~km}$ of continental extension, the amount estimated across the thinned continental-margin crust of the velocity model. It is likely that the low-lying crust of the coastal plain beyond our transect to the southeast also was extended. 
The Alarcón segment is a wide rift. This segment experienced $350 \mathrm{~km}$ of continental extension prior to the onset of seafloor spreading at 2-3 Ma, which has produced $\sim 135 \mathrm{~km}$ of oceanic crust $\sim 6 \mathrm{~km}$ thick ${ }^{15}$. The continent/ocean boundary is marked by a sharp transition from a shallowing to a flat Moho below normal-thickness oceanic crust with clearly identifiable magnetic anomalies (Sup. Inf. Fig. S1). In this segment, the transition to seafloor spreading appears coincident with the northward propagation of the $\mathrm{EPR}^{6,18}$. Earlier, extension localized beneath the Tamayo trough, thinned the continental crust there to $\sim 7 \mathrm{~km}$, but left little evidence there or elsewhere within the segment for syn-rift magmatism apart from a 250- to 500-m-thick, 2.5- to 2.8$\mathrm{km} / \mathrm{s}$ layer overlying basement along much of the transect that may represent volcanic or volcaniclastic strata ${ }^{15}$. The Alarcón segment was thus magma-poor during rifting, suggesting that the underlying "continental” asthenospheric mantle did not readily melt upon decompression. We speculate that, as the EPR propagated northward, dikes sourced from the presumably more fertile EPR asthenospheric mantle ultimately enabled rupturing of the continental lithosphere ${ }^{19}$.

The Cabo-PV segment is a narrow rift. The continent/ocean boundary at the western margin is similar to that in Alarcón, juxtaposing EPR-sourced oceanic crust against extended continental crust. In this segment, however, seafloor spreading initiated $\sim 1$ m.y. prior to the propagation of the EPR into the gulf at $\sim 3.5 \mathrm{Ma}$. The initial spreading centre is preserved in the southeast as the María Magdalena Rise ${ }^{6,20}$. The crust produced at the Magdelena Rise was presumably derived from “continental” asthenosphere and is $\sim 1 \mathrm{~km}$ thicker than the crust formed at the EPR. The EPR propagated into the segment along the western continent/ocean boundary, and it is believed that a brief period of coincident spreading at the two spreading centres resulted in convergence along the eastern margin ${ }^{6}$. Estimating pre-rift extension in this segment is thus complicated, but the steep western margin indicates that this is a narrow rift segment 
(Sup. Inf. Fig. S5). There is little direct evidence of syn-rift magmatism in this segment, but the rapid transition to magmatic seafloor spreading suggests that this segment is neither magma poor nor magma rich and that the underlying continental asthenosphere produced melt as would be expected during rifting.

The crustal structure of the Alarcón segment challenges the common notion of how wide rifts form. A mechanism of wide-rift formation in which buoyancy-driven lowercrustal flow inhibits localization ${ }^{1,4}$ does not apply to this segment, since substantial Moho topography persists to the present. The localized extension beneath the Tamayo trough indicates that the lithosphere resisted rupture even after substantial thinning, suggesting that the lithospheric mantle was strong and that the asthenosphere did not produce sufficient melt to rupture the lithosphere via diking ${ }^{19}$ prior to the arrival of the presumably more fertile EPR mantle. The adjacent Pescadero and Farallón segments north of Alarcon have rifted-margin morphologies that are similar to Alarcón (Supp. Info. Fig. S5). These segments differ from Alarcón in that their spreading centres are defined by narrow bathymetric deeps that indicate only nascent, or no, seafloor spreading. (Supp. Info. Figs. S4-6). This suggests that the EPR mantle has not propagated into them and that these are also magma poor segments underlain by continental mantle that does not readily melt. We call these wide-rift segments collectively the south-central domain.

The south-central segments rifted over the locus of voluminous early-Miocene ignimbrite volcanism ${ }^{21}$ (Fig. 1). This early Miocene event, which followed a more extensive early Oligocene event, deposited 1-2 km of ignimbrite and lava over a wide area and may have left the residual mantle both depleted and dry, reducing its ability to melt and deform ${ }^{22}$. Magmatic depletion of the mantle may thus be a primary factor controlling the evolution of rifting in the south-central domain. The relatively abrupt transition in rift style between the south-central domain and the surrounding segments 
may be related to the focused magmatism characteristic of volcanic arcs, evidenced by their long-lived volcanic centres, which may be manifest partly in the mantle. Alternatively, the triggering mechanism of ignimbrite magmatism, perhaps slab foundering ${ }^{21}$, may have been laterally discontinuous. Either situation could enable voluminous arc volcanism to impart depleted mantle signatures that vary over small spatial scales, thus explaining the relatively abrupt variation in rifting style between the south-central domain and the segments to the north and south.

Magmatism within the Guaymas basin is anomalous with respect to the southcentral segments and with respect to globally averaged mid-ocean ridge crustal production ${ }^{23}(\sim 6 \mathrm{~km})$. The average thickness of the plutonic component of new igneous crust (average $V_{\mathrm{P}}=6.8 \mathrm{~km} / \mathrm{s}$ ) in the northern Guaymas segment is greater than $7 \mathrm{~km}$, and velocities of 4.0-5.5 km/s in the overlying 2- to 3-km-thick layer of sediments and igneous rocks ${ }^{24}$ suggest an additional $1 \mathrm{~km}$ or more equivalent igneous thickness. It is likely that the southern Guaymas segment, which hosts a basaltic shield volcano ${ }^{25}$, is similarly magmatic. It is possible that the underlying mantle here is more fertile and/or hotter than that beneath the south-central domain and the average MORB-source mantle. The mantle may be "charged" ${ }^{26}$ in a similar fashion to how the mantle beneath the southcentral domain was charged prior to the early Miocene ignimbrite event. That ignimbrite event did not extend northward beneath the Guaymas basin, however, and so the inherited fertility/hydration beneath Guaymas basin has been expressed as ongoing robust magmatism since continental breakup, with this magmatism probably contributing to lithospheric rupture after only moderate extension.

A second factor possibly contributing to the anomalous magmatism in Guaymas basin may also explain crustal structure within the northern gulf and has implications for sedimented spreading centres and mantle melt extraction generally. The crustal structure 
of the Delfín-Tiburón segment in the northern gulf ${ }^{14}$ is similar to the northern Guaymas segment, with a thick layer ( $>5 \mathrm{~km}$ ) of intruded sediments overlying a thick igneous layer with mafic (6.5-6.8 km/s) seismic velocities. Geologic evidence suggests that 275 km of extension has occurred across the Delfín-Tiburón segment between points separated by $300 \mathrm{~km}^{27}$ (Fig. 1), and so it is likely that most of this extension was accommodated by the creation of new igneous crust. A common feature shared by the Guaymas and Delfín-Tiburón segments, and not shared by the Cabo-PV segment, is a thick sedimentary layer, and we speculate that this sediment blanket may enhance mantle melt extraction. It is unlikely that melt extraction beneath mid-ocean ridges is $100 \%$ efficient, and so the global average oceanic crustal thickness likely underestimates the available melt. The thermal structure near mid-ocean ridges may place controls on melt extraction $^{28}$, and hydrothermal circulation is a robust mechanism for enhancing heat flux $^{29}$. It might thus be expected that a thick blanket of sediment, by inhibiting hydrothermal circulation, would enhance melt extraction, resulting in new igneous crust thicker than that at unsedimented mid-ocean ridges.

The results presented here highlight the importance of inherited mantle fertility/hydration and possibly of sediments as controlling parameters of the rifting process. The primary observations are variations in rift width and magmatism over small spatial scales, with wide, magma-poor rift segments formed over mantle that sourced voluminous pre-rift, arc magmatism, and magma-rich segments associated with thick sediments. Many rifts initiate or localize at formerly convergent boundaries in response to ridge subduction, in back-arc settings, or along suture zones following continent/continent collision. Substantial along-strike variations in the expression of rifting, with these variations controlled by pre-rift tectonics and magmatism of the formerly convergent margin, may thus be common along many rifted margins. Similarly, 
substantial along-strike variability in syn-rift sedimentation is likely in many rifts, depending on topography, climate, and regional drainage patterns. 


\section{References}

1. Hopper, J. R. \& Buck, W. R. The effect of lower crustal flow on continental extension and passive margin formation. J. Geopys. Res. 101, 21,175-20,194, 1996.

2. Braun, J. \& Beaumont, C. Styles of continental rifting from dynamical models of lithospheric extension. Mem. Can. Soc. Pet. Geol. 12, 241-258, 1987.

3. England, P. C., Constraints on extension of continental lithosphere. J. Geophys. Res. 88, 1145-1152, 1983.

4. Buck, W. R., Lavier, L. L. \& Poliakov, A. N. B. How to make a rift wide. Phil. Trans. R. Soc. Lon. 357, 671-693, 1999.

5. McKenzie, D. \& Bickle, M. J. The volume and composition of melt generated by extension of the lithosphere. J. Petrol. 29, 625-679, 1988.

6. Lonsdale, P. Geology and tectonic history of the Gulf of California, in The Eastern Pacific Ocean and Hawaii, edited by Winterer, E. L., Hussong, D. M. \& Decker, R. W., The Geology of North America N, Geological Society of America, pp. 499-521, 1989.

7. Atwater, T. M. Implications of plate tectonics for the Cenozoic evolution of western North America. Geol. Soc. Amer. Bull. 81, 3513-3536, 1970.

8. Menard, H. W. Fragmentation of the Farallon plate by pivoting subduction. J. Geol. 86, 99-110, 1978.

9. Stock, J. M. \& Lee, J. Do microplates in subduction zones leave a geological record? Tectonics, 13, 1472-1487, 1994.

10. Michaud, F., Royer, J. Y., Bourgois, J., Dyment, J., Calmus, T., Bandy, W., Sosson, M., Mortera-Gutiérrez, C., Sichler, B., Rebolledo-Viera, M. \& Pontoise, B. Oceanicridge subduction vs. slab break off: Plate tectonic evolution along the Baja California Sur continental margin since 15 Ma. Geology 34, 13-16, doi:10.1130/G22050.1, 2006. 
11. DeMets, C. \& Dixon, T. H. New kinematic models for Pacific-North America motion from 3 Ma to present; I, Evidence for steady motion and biases in the NUVEL-1A model. Geophys. Res. Let., 26, 1921-1924.

12. Dixon, T. H., Farina, F., DeMets, C., Suarez-Vidal, F., Fletcher, J., Marquez-Azua, B., Miller, M., Sanchez, O. \& Umhoefer, P. J., New kinematic models for Pacific-North America motion from 3 Ma to present; II, Evidence for a "Baja California shear zone”. Geophys. Res. Let., 26, 1921-1924.

13. Phillips, R. P. Seismic refraction studies in Gulf of California, in Marine geology of the Gulf of California, AAPG Memoir, 3, edited by van Andel, T. \& Shor, G. G., pp. 90125, 1964.

14. González-Fernández, A., Dañobeitia, J. J., Delgado-Argote, L. A., Michaud, F., Córdoba, D. \& Bartolomé, R. Mode of extension and rifting history of upper Tiburón and upper Delfín basins, northern Gulf of California. J. Geophy. Res. 110, doi:10.1029/2003JB002941, 2005.

15. Sutherland, F. H. "Continental Rifting Across the Southern Gulf of California", Ph.D. Thesis, Univ. of California, San Diego, 2006.

16. Paramo, P. "Seismic Studies of Continental Rupture and Ocean Finestructure in the Gulf of California", Ph. D. Thesis, Univ. of Wyoming, 2006.

17. Brown, H. E., Paramo, P., Holbrook, W. S., Lizarralde, D., Kent, G., Harding, A., Gonzalez, A., Fletcher, J., Umhoefer, P. \& Axen, G. Crustal structure of the southern Gulf of California and subducting Rivera plate. Eos Trans., 87, Fall Meet. Suppl., T41D1607, 2006.

18. Castillo, P. R., Hawkins, J. W., Lonsdale, P. F., Hilton, D. R., Shaw, A. M. \& Glascock, M. D. Petrology of Alarcon Rise lavas, Gulf of California: Nascent intracontinental ocean crust. J. Geophy. Res. 107, doi:10.1029/2001JB000666, 2002. 
19. Buck, W. R. The role of magma in development of the Afro-Arabian rift system, in The Afar Volcanic Province Within the East African Rift System, Geol. Soc. Spec. Pub., 259, edited by Yirgu, G., Ebinger, C. J. \& Maguire, P. K. H., pp. 43-54, 2006.

20. Larsen, R. L. Bathymetry, magnetic anomalies, and plate tectonic history of the mouth of the Gulf of California. Geol. Soc. Amer. Bull. 83, 3345-3360, 1972.

21. Ferrari, L., Valencia-Moreno, M. \& Bryan, S. Magmatismo y tectónica en la Sierra Madre Occidental y su relación con la evolución de la margen occidental de Norteamérica. Bull. Geol. Soc. Mexico 57, 343-378, 2005.

22. Hirth, G. \& Kohlstedt, D .L. Water in the oceanic upper mantle: Implications for rheology, melt extraction, and the evolution of the lithosphere. Earth. Planet. Sci. Lett. 144, 93-108, 1996.

23. White, R.S., McKenzie, D. \& O’Nions, R.K. Oceanic crustal thickness from seismic measurements and rare earth element inversions. J. Geophys. Res. 97, 19,683-19,715, 1992.

24. Einsele, G., Curray, J. M., Moore, D. M., Aguayo, E., Aubry, M. P., Fornari, D., Guerrero, J., Kastner, M., Kelts, K., Lyle, M., Matoba, Y., Molina-Cruz, A., Niemitz, J., Rueda, J., Saunders, A., Schrader, H., Simoneit, B. \& Vacquier, V. Intrusion of basaltic sills into highly porous sediments, and resulting hydrothermal activity. Nature, 283, 441445, 1980.

25. Batiza, R., Geology, petrology, and geochemistry of Isla Tortuga, a recently formed tholeiitic island in the Gulf of California. Geol. Soc. Amer. Bull., 89, 1309-1324, 1978.

26. Humphreys, E., Hessler, E., Dueker, K., Erslev, E., Farmer, G. L. \& Atwater, T. How Laramide-age hydration of North America by the Farallon slab controlled subsequent activity in the western U.S., in The George A. Thompson Volume, International Book 
Series, 7, edited by Klemperer, S. L. \& Ernst, W. G., pp. 524-544, Geological Society of America, 2003.

27. Oskin, M., Stock, J. M. \& Martín-Barajas, A. Rapid localization of Pacific-North America plate motion in the Gulf of California. Geology 29, 459-462, 2001.

28. Brown, J. W. \& White, R. S. Effect of finite extension rate on melt generation at rifted continental margins. J. Geophys. Res. 100, 18,011-18,029, 1995.

29. Johnson, H. P. \& Pruis, M. J. Fluxes of fluid and heat from the oceanic crustal reservoir. Earth. Planet. Sci. Lett. 216, 565-574, doi:10.1016/50012-812X(03)00545-2, 2003.

30. Zelt, C. A. \& Smith, R. B. Seismic traveltime inversion for 2-D crustal velocity structure, Geophys. J. Int. 108, 16-34, 1992. 
Supplementary Information is linked to the online version of the paper at www.nature.com/nature.

Acknowledgements We thank the captains and crew of the R/V Maurice Ewing and R/V New Horizon, the OBSIP teams, J. Urban, and A. Gorman for his efforts as Chief Scientist on the R/V New Horizon. The Lamont Earth Observatory Marine Office and CICESE provided invaluable support before and during the experiment. This work was funded by a grant from the U.S. NSF-MARGINS program.

Author Contributions D.L., P.J.U., G.M.K., W.S.H., A.J.H., A.G.F., J.M.F., and G.J.A. were the principle investigators on this project and each contributed substantially to this work. F.S., P.P., and H.E.B. analysed data from the Alarcón and Cabo-PV segments as portions of their Ph.D. theses. D.L. analysed data from Guaymas and wrote the paper. All authors discussed the results and commented on the manuscript.

Author Information Reprints and permissions information is available at npg.nature.com/reprintsandpermissions. The authors declare no competing financial interests. Correspondence and requests for materials should be addressed to D.L. (danl@whoi.edu). 


\section{Figure Captions}

Figure 1. Map of the PESCADOR experiment in southern Gulf of California. Guaymas, Carmen, Farallón, Pescadero, Alarcón, and San José del CaboPuerto Vallarta segments separated by dashed lines and labelled G, C, F, P, A, $\mathrm{C}-\mathrm{PV}$, blue for south-central segments; white and red dots are instrument locations of the three seismic transects; white shading indicates extent of early Miocene ignimbrite volcanism ${ }^{21}$. Inset: Green shading, northern; pink, EPRsourced crust; extinct and modern plate boundaries in blue and red; A.B., Agua Blanca; white and blue dots, CORTES-P96 ${ }^{14}$ instruments; geologic constraints on northern gulf spreading ${ }^{27}$ indicated by yellow stars; and mapped extent ${ }^{21}$ of Oligicene (yellow shading) and early Miocene (purple) ignimbrite events.

Figure 2. Models of seismic velocity structure along the Guaymas, Alarcón and Cabo-PV transects of the PESCADOR experiment. Velocity contours are labelled in $\mathrm{km} / \mathrm{s}$. Yellow diamonds are instrument locations. COT indicates interpreted continent/ocean transition. Dashed line in the Cabo-PV model indicates interpreted boundary between oceanic crust formed at the Magdalena Rise and the EPR. Models were determined using a combined forward/inverse travel time modelling approach ${ }^{30}$. Examples of data are presented in the Supplementary Information. 


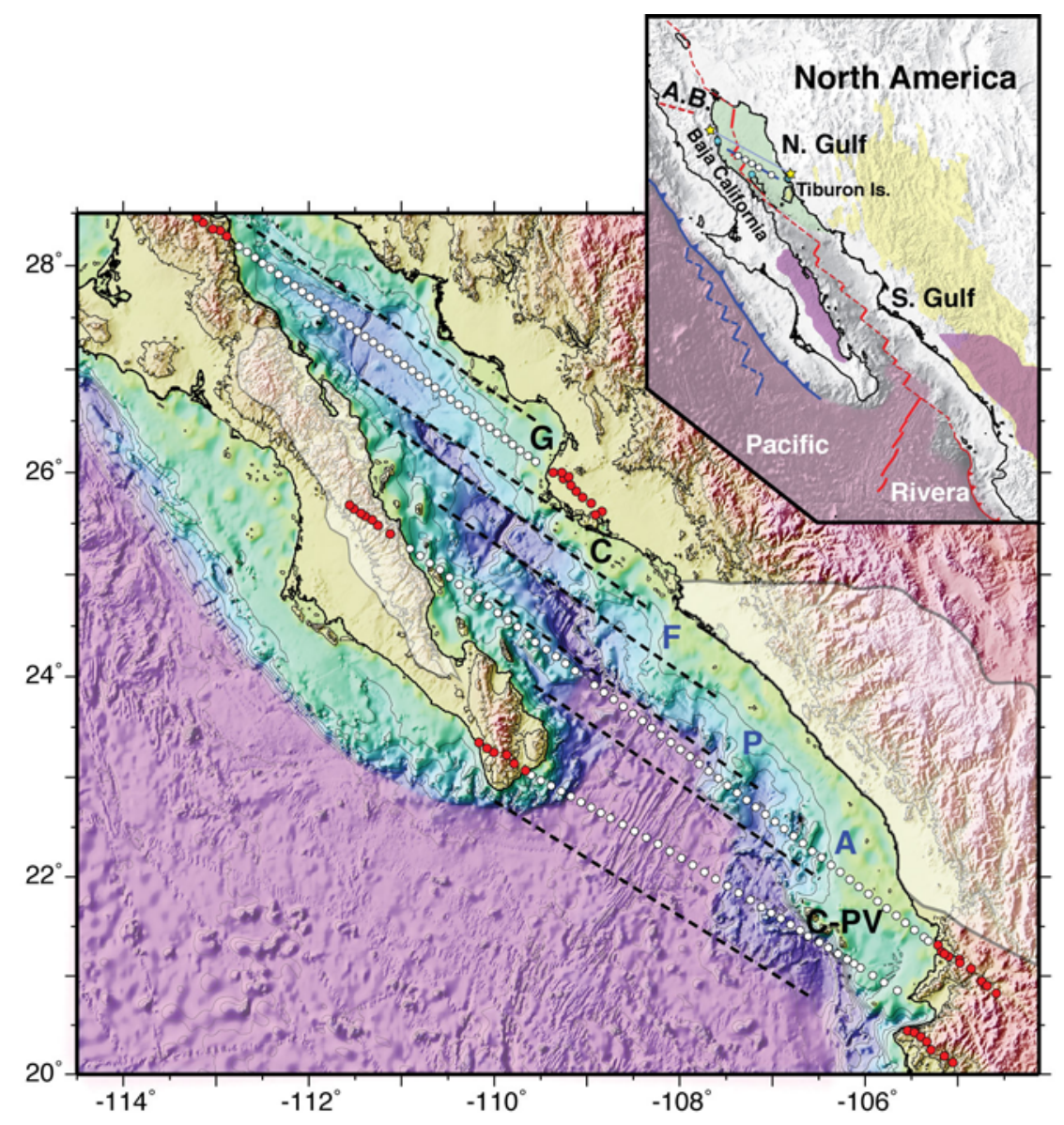

Figure 1 


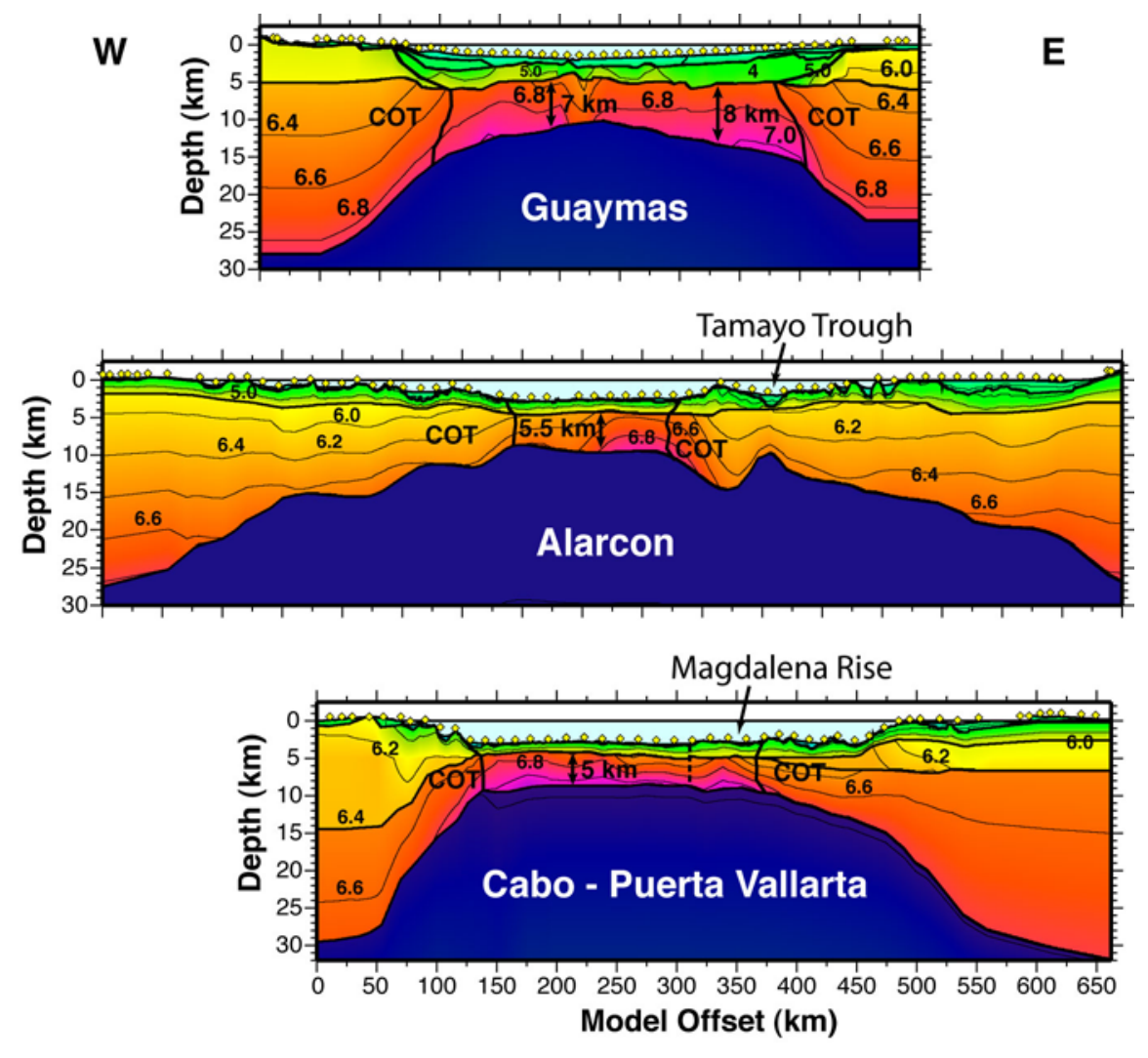

Figure 2 